\title{
Advanced non-small cell lung cancer: on relapse rechallenge the tumor, not the patient
}

\author{
Marios E Froudarakis ${ }^{1 *}$, Evangelos Briasoulis ${ }^{2}$
}

Non-small cell lung cancer (NSCLC) is the leading cause of cancer-related mortality in the world. The majority of NSCLC patients are diagnosed with advanced-stage disease and almost all except a tiny minority will develop incurable metastatic disease. The standard of care for such patients with a good performance status (PS) is currently platinum based chemotherapy, which can offer palliation of symptoms but only modest survival improvement [1-3]. Nearly all patients who receive systemic therapy for advanced-metastatic NSCLC will eventually relapse [4]. This is an unquestionable reality. Physicians who deal with medical management of NSCLC patients who failed first line therapy are often puzzled with three key questions: if, what, and whom, to offer a second line therapy. Existing evidence is unfortunately weak, if not confusing, to address such issues. It is therefore apparent that for optimal medical management of these patients we need molecular and/or clinical biomarkers to safe-guide therapeutic decisions.

Randomized clinical trials have shown that second-line chemotherapy in NSCLC patients who failed or relapsed first-line therapy, can offer modest and marginal survival benefits at the cost of considerable toxicity. Yet patients enrolled in such studies were not quite representative of this group of patients [5]. Treatment options available for previously treated advanced-metastatic NSCLC are single agent docetaxel, pemetrexed, and epidermal growth factor receptor inhibitors (erlotinib and gefitinib) [6]. It should be stressed herein that only single-agent therapies have been approved and are recommended for clinical use in this clinical setting. Combination chemotherapy failed to show survival benefits when compared with single agent treatment in the clinical setting of second line chemotherapy but increased toxicity [7]. Results were also disappointing when chemotherapy was combined with anti-VEGF antibody bevacizumab [8].

\footnotetext{
* Correspondence: mfroud@med.duth.gr

'Department of Pneumonology, Medical School of Alexandroupolis, Democritus University of Thrace, Greece
}

Approximately $30 \%$ of patients with advancedmetastatic NSCLC will also receive second-line chemotherapy [9]. It is therefore obvious that we need biomarkers to help us select patients who have chances to get benefit from therapy and pick the best therapeutic option for each individual. Several investigators have tried to profile NSCLC patients who can tolerate second line chemotherapy $[10,11]$. Treatment tolerability is always a significant parameter for patients who are offered palliative therapy. In advanced NSCLC, patients with a poor performance status (PS 2 and worse) have shown to fare poorly to platinum-based doublets even when treatment is given upfront [12]. Although newer agents have been tested in doublets or in combination with novel platinum compounds [13], no benefit was observed when compared to single agent chemotherapy [7]. Currently it is recommended that such patients should be offered single-agent chemotherapy to low the risk of unwanted toxicity, which is expected high in such cases [6,7]. Moreover, there is no evidence to support second-line treatment of patients with poor performance status [14].

A recent analysis, which included data from 1239 patients, demonstrated that prognosis is significantly influenced by gender (worse in males), PS, tumor histology (worse in squamous and other histology versus adenocarcinoma), stage (worse in IV versus IIIB), type of previous treatment (worse for patients pretreated with platinum) and response to first-line (worse for patients not obtaining objective response). The authors devised a summary index (score) that could discriminate patients into three categories according to probability of survival [11]. However, prospective studies aiming to identify patients with relapsed advanced-metastatic NSCLC who might be benefited of second-line chemotherapy are surprisingly missing. The paper of Belbaraka et al. [15], from Centre Léon Bérard, Lyon, France, stresses this issue in a prospective way. The authors identified poor PS as the primary indicator for failure to second line chemotherapy. Despite its limitations, (i.e. small number of patients, heterogeneity of chemotherapy administered 
and lack of quality-of-life data), this prospective study showed that poor PS should make treating physicians reluctant in advising second-line chemotherapy for patients with relapsed NSCLC [15].

Nevertheless it should be noticed that chemotherapy is not the only systemic therapy available for NSCLC patients today. Small molecule inhibitors of cancer-associated disordered epidermal growth factor receptor (EGFR) are now approved for NSCLC patients with EGFR mutated tumors [16]. We have previously proclaimed that personalized therapeutic management based on molecular predictors should be considered the most proper approach in terms of good clinical practice, in the era of cancer targeted therapy [17]. Interestingly, it has been shown that such therapies can substantially benefit patients if only offered to molecularly defined target populations irrespectively of previous therapy. A recent study showed that gefitinib is equally effective in patients affected by EGFR mutated tumors in chemonaive patients and in chemotherapy-treated patients [18-20].

Whether we should treat patients who relapse after second line chemotherapy is another issue [21]. Massarelli et al. conducted a retrospective analysis of over 700 patients who had received two or more prior chemotherapy regimens for recurrent-metastatic NSCLC. They found that median survival and response rates decreased steadily with each subsequent regimen. The objective responses became infrequent and of short duration and toxicities increased considerable [22]. Understandably, the vast majority of patients who receive second-line therapy are not expected to qualify for a third-line treatment, because of compromised organ functions, clinical deterioration and development of resistance to chemotherapeutics. Besides, we lack phase III data to support routine use of chemotherapy in the third-line setting [3]. For these patients, supportive care is the only reasonable option, in addition to experimental treatments in clinical trials [3].

Symptom palliation and Quality of Life are primary goals of therapy for patients with advanced-metastatic NSCLC upon tumor relapse. Therefore, «gentle» effective therapies, as are weekly and metronomic regimens should rather be favored in cases of relapsed NSCLC patients who are at risk of severe toxicity [23,24].

Finally, when making treatment decisions for patients with relapsed advanced NSCLC we, physicians, should always be simple and wise in our approach. As a rule of thumb, we should preferably opt a targeted or gentle therapy and should let patient's performance status remind us that we may try rechallenge the tumor but not the patient.

\section{Author details}

'Department of Pneumonology, Medical School of Alexandroupolis, Democritus University of Thrace, Greece. ${ }^{2}$ Department of Medical Oncology, Medical School, University of Ioannina, Greece.

\section{Authors' contributions}

MEF and EB have contributed equally to this manuscript.

\section{Competing interests}

The authors declare that they have no competing interests.

Received: 16 June 2010 Accepted: 14 July 2010 Published: 14 July 2010

\section{References}

1. Herbst RS, Heymach JV, Lippman SM: Lung cancer. N Engl J Med 2008, 359(13):1367-1380

2. Stinchcombe TE, Socinski MA: Current treatments for advanced stage non-small cell lung cancer. Proc Am Thorac Soc 2009, 6(2):233-241.

3. Azzoli CG, Baker S Jr, Temin S, Pao W, Aliff T, Brahmer J, Johnson DH, Laskin JL, Masters G, Milton D, et al: American Society of Clinical Oncology Clinical Practice Guideline update on chemotherapy for stage IV nonsmall-cell lung cancer. J Clin Oncol 2009, 27(36):6251-6266.

4. Gridelli C, Ardizzoni A, Ciardiello F, Hanna N, Heymach JV, Perrone F, Rosell R, Shepherd FA, Thatcher N, Vansteenkiste J, et al: Second-line treatment of advanced non-small cell lung cancer. J Thorac Oncol 2008, 3(4):430-440.

5. Sabir A, Schor-Bardach R, Wilcox CJ, Rahmanuddin S, Atkins MB, Kruskal JB, Signoretti S, Raptopoulos VD, Goldberg SN: Perfusion MDCT enables early detection of therapeutic response to antiangiogenic therapy. AJR Am J Roentgenol 2008, 191(1):133-139.

6. Stahel RA: Non-small cell lung cancer: second-line and beyond. Ann Oncol 2006, 17(Suppl 10):x97-100.

7. Noble J, Ellis PM, Mackay JA, Evans WK: Second-line or subsequent systemic therapy for recurrent or progressive non-small cell lung cancer: a systematic review and practice guideline. J Thorac Oncol 2006, 1(9):1042-1058.

8. Adjei AA, Mandrekar SJ, Dy GK, Molina JR, Gandara DR, Ziegler KL, Stella PJ, Rowland KM Jr, Schild SE, Zinner RG: Phase II trial of pemetrexed plus bevacizumab for second-line therapy of patients with advanced nonsmall-cell lung cancer: NCCTG and SWOG study N0426. J Clin Oncol 2010, 28(4):614-619.

9. Stinchcombe TE, Socinski MA: Considerations for second-line therapy of non-small cell lung cancer. Oncologist 2008, 13(Suppl 1):28-36.

10. Hensing TA, Schell MJ, Lee JH, Socinski MA: Factors associated with the likelihood of receiving second line therapy for advanced non-small cell lung cancer. Lung Cancer 2005, 47(2):253-259.

11. Di Maio M, Lama N, Morabito A, Smit EF, Georgoulias V, Takeda K, Quoix E, Hatzidaki D, Wachters FM, Gebbia V, et al: Clinical assessment of patients with advanced non-small-cell lung cancer eligible for second-line chemotherapy: a prognostic score from individual data of nine randomised trials. Eur J Cancer 46(4):735-743.

12. Schiller JH, Harrington D, Belani CP, Langer C, Sandler A, Krook J, Zhu J, Johnson $\mathrm{DH}$ : Comparison of four chemotherapy regimens for advanced non-small-cell lung cancer. N Engl J Med 2002, 346(2):92-98

13. Froudarakis ME, Pataka A, Pappas P, Anevlavis S, Argiana E, Nikolaidou M, Kouliatis G, Pozova S, Marselos M, Bouros D: Phase 1 trial of lipoplatin and gemcitabine as a second-line chemotherapy in patients with nonsmall cell lung carcinoma. Cancer 2008, 113(10):2752-2760.

14. Bonfill X, Serra C, Sacristan M, Nogue M, Losa F, Montesinos J: Second-line chemotherapy for non-small cell lung cancer. Cochrane Database Syst Rev 2002(2):CD002804

15. Belbaraka R, Trédan O, Ray-Coquard I, Chvetzoff G, Bajard A, Pérol D, Ismaili N, Ismaili M, Errihani H, Bachelot T, et al: Factors of interrupting chemotherapy in patients with Advanced Non-Small-Cell Lung Cancer. BMC Res Notes 2010, 3:164.

16. Mok TS, Wu YL, Thongprasert S, Yang CH, Chu DT, Saijo N, Sunpaweravong P, Han B, Margono B, Ichinose Y, et al: Gefitinib or carboplatin-paclitaxel in pulmonary adenocarcinoma. N Engl J Med 2009, 361(10):947-957. 
17. Roukos DH, Murray S, Briasoulis E: Molecular genetic tools shape a roadmap towards a more accurate prognostic prediction and personalized management of cancer. Cancer Biol Ther 2007, 6(3):308-312.

18. Linardou H, Dahabreh IJ, Bafaloukos D, Kosmidis P, Murray S: Somatic EGFR mutations and efficacy of tyrosine kinase inhibitors in NSCLC. Nat Rev Clin Oncol 2009, 6(6):352-366.

19. Wu JY, Yu CJ, Yang CH, Wu SG, Chiu YH, Gow CH, Chang YC, Hsu YC, Wei PF, Shih JY, et al: First- or second-line therapy with gefitinib produces equal survival in non-small cell lung cancer. Am J Respir Crit Care Med 2008, 178(8):847-853.

20. Dahabreh IJ, Linardou H, Siannis F, Kosmidis P, Bafaloukos D, Murray S: Somatic EGFR mutation and gene copy gain as predictive biomarkers for response to tyrosine kinase inhibitors in non-small cell lung cancer. Clin Cancer Res 2010, 16(1):291-303.

21. Yang $\mathrm{CH}$ : Third-line chemotherapy for advanced non-small-cell lung cancer-is there enough evidence to support its use? J Chin Med AssoC 2005, 68(4):160-161.

22. Massarelli E, Andre F, Liu DD, Lee JJ, Wolf M, Fandi A, Ochs J, Le Chevalier T, Fossella F, Herbst RS: A retrospective analysis of the outcome of patients who have received two prior chemotherapy regimens including platinum and docetaxel for recurrent non-small-cell lung cancer. Lung Cancer 2003, 39(1):55-61.

23. Gervais R, Ducolone A, Breton JL, Braun D, Lebeau B, Vaylet F, Debieuvre D, Pujol JL, Tredaniel J, Clouet P, et al: Phase II randomised trial comparing docetaxel given every 3 weeks with weekly schedule as second-line therapy in patients with advanced non-small-cell lung cancer (NSCLC). Ann Oncol 2005, 16(1):90-96.

24. Briasoulis E, Pappas P, Puozzo C, Tolis C, Fountzilas G, Dafni U, Marselos M, Pavlidis N: Dose-ranging study of metronomic oral vinorelbine in patients with advanced refractory cancer. Clin Cancer Res 2009, 15(20):6454-6461.

doi:10.1186/1756-0500-3-195

Cite this article as: Froudarakis and Briasoulis: Advanced non-small cell lung cancer: on relapse rechallenge the tumor, not the patient. $B M C$ Research Notes 2010 3:195.

\section{Submit your next manuscript to BioMed Central and take full advantage of:}

- Convenient online submission

- Thorough peer review

- No space constraints or color figure charges

- Immediate publication on acceptance

- Inclusion in PubMed, CAS, Scopus and Google Scholar

- Research which is freely available for redistribution

Submit your manuscript at www.biomedcentral.com/submit
Biomed Central 